УДК 330

DOI: https://doi.org/10.37320/2415-3583/18.11

Шульга О.А.

доктор економічних наук, доцент

Державний університет інтелектуальних технологій $і$ зв'язку

\title{
СУЧАСНІ ПІДХОДИ ДО РОЗРОБЛЕННЯ Й УПРОВАДЖЕННЯ ІНФОРМАЦЙНИХ СИСТЕМ УПРАВЛІННЯ ПІДПРИЕМСТВОМ: ТЕОРЕТИКО-МЕТОДОЛОГІЧНИЙ АСПЕКТ
}

У статті дано характеристику формальних та неформальних інформаційних систем. Зазначено, щчо у практииі розроблення інформаџійних систем застосовуються такі види стратегій: підхід від організаиійної структури; підхід із відкладеною інтеграцією; підхід, щео базується на зборі даних; підхід, заснований на використанні баз даних; підхід «зверху вниз»; загальносистемний підхід та підхід, керований подіями. Розкрито сутність та зміст підходів до розроблення й упровадження інформаиійних систем управління підприємством, проведено їх порівняльну характеристику. Дано характеристику структурних та об'єктно-орієнтованих методів розроблення інформаційних систем підприємства. Зроблено акцент на тому, щчо основними перевагами використання інформачійних технологій в управлінні підприємством є: зниження витрат, оптимізація обліку та контролю, забезпечення прозорості інформації для інвесторів. можливість збільшення частки ринку тощьо.

Ключові слова: підходи, методи, інформачійні системи, інформаційні технологї̈, стратегї.

Постановка проблеми. Одним 3 ефективних напрямів удосконалення управління підприємством $є$ розроблення та впровадження сучасних інформаційних систем управління і технологій. Світова практика свідчить, що інформаційні системи є потужним інструментом підвищення продуктивності праці та ефективності виробництва. Використання сучасних програмних продуктів позитивно впливає на ефективність діяльності підприємства та підвищення його конкурентоспроможності. До основних переваг використання інформаційних технологій в управлінні підприємством належать: зниження впливу людського фактора, зниження витрат, оптимізація обліку та контролю, забезпечення прозорості інформації для інвесторів, можливість збільшення частки ринку тощо.

Аналіз останніх досліджень і публікацій. Дослідженнями теоретичних та практичних аспектів застосування сучасних інформаційних технологій у різних сферах діяльності займалися такі вчені, як: І. Балабанов, І. Білоброва, І. Гавриленко, М. Карпенко, Н. Манакова, С. Ілляшенко, Н. Пікуліна, Д. Сушко, С. Філіна та ін. Водночас вивченню сучасних підходів до розроблення й упровадження інформаційних систем управління підприємством із метою надання рекомендацій щодо їх удосконалення, на нашу думку, приділено недостатньо уваги.

Мета статті полягає в узагальненні існуючих теоретико-методичних підходів до розроблення й упровадження інформаційних систем управління підприємством.

Виклад основного матеріалу. Інформаційна технологія - це процес, що використовує сукупність засобів і методів збору, накопичення, обробки та передачі даних (первинної інформації) для отримання оновлених даних про стан об'єкта, процес або явище (інформаційний продукт). Основною метою інформаційної 
технології $є$ обробка первинної інформації за допомогою цілеспрямованих дій та отримання необхідної користувацької інформації, а також отримання та обробка даних для їх подальшого аналізу і прийняття рішень про виконання певної дії.

На підприємстві існують формальні та неформальні організаційні комп'ютерні інформаційні системи. Формальні системи опираються на прийняті й упорядковані дані та процедури збору, зберігання, виготовлення, поширення і використання цих даних. Неформальні інформаційні системи базуються на неявних угодах i неписаних правилах поведінки. Тобто немає ніяких правил, що $є$ інформацією або як вона буде накопичуватися й оброблятися. Такі системи необхідні для життя організації, і до інформаційних технологій вони мають досить віддалене відношення.

Сучасна інформаційна система управління підприємством повинна містити у собі максимально можливий комплекс функцій для управління всіма бізнеспроцесами підприємства. Подібну функціональність охоплюють системи ERP, які можуть забезпечити для підприємства: управління фінансами; планування та управління виробництвом; управління розміщенням запасів; управління реалізацією і маркетингом; управління постачанням; управління проєктами; управління сервісним обслуговуванням; управління процедурами забезпечення якості продукції.

Інформаційна система підприємства створюється для вдосконалення управління ним та забезпечує нерозривний зв'язок між інформацією та управлінням. Створення інформаційної системи підприємства передбачає розроблення низки підсистем, які мають відповідати принципам інтеграції та керованості. Істотний вплив на розроблювальну інформаційну систему підприємства має стратегія (або система поглядів) щодо іiї організації. Інформаційна стратегія повинна повною мірою відповідати цілям та завданням, які стоять перед підприємством, перш за все, у сфері основного бізнесу, а також сприяти реалізації конкурентних переваг підприємства на ринку. Стратегія розвитку інформаційних технологій підприємства повинна безпосередньо випливати зі стратегії компанії [2].

Під час розроблення інформаційної стратегії необхідно передусім глибоко розуміти бізнес-стратегію підприємства та роль інформаційних технологій у структурі підприємства. Роль інформаційних технологій залежно від виду діяльності на підприємстві може варіюватися від базової підтримки та забезпечення безперебійної роботи IT-інфраструктури і сервісів до визначальної та життєво важливої в основних бізнеспроцесах. Найскладнішим у галузі розроблення інформаційної стратегії $€$ не визначення та розуміння напрямів розвитку інформаційних технологій і необхідних інвестицій, а вміння практично застосовувати накопичений досвід. Сам процес визначається досить просто: визначення бізнес-цілі, вимоги, проблеми, завдання, IT-рішення.

Основу під час визначення інформаційної стратегії становить інформація про користувачів, яку вдається зібрати у процесі проведення аналізу бізнес-процесів підприємства. Знання бізнесу та вимоги користувача трансформуються в бізнес-цілі IT-департаменту та плани їх досягнення. Що стосується самої інформацій- ної системи підприємства, то вона повинна бути складовою частиною інформаційної стратегії.

Стратегія розроблення інформаційних систем повинна допомагати приймати рішення, тобто в ній повинні бути відповіді на найважливіші питання, які виникатимуть протягом найближчих років. Наприклад: визначено стратегічні завдання інформаційних технологій у цілому виходячи з бізнес-завдань і функції підрозділу у компанії; визначено функцію IT-служби у компанії, проведено аналіз стану ІT-підрозділу по відношенню до компанії; визначено загальні підходи до реалізації стратегічних завдань. Щодо оцінки ризиків упровадження, то вони повинні оцінюватися до початку впровадження та купівлі самої інформаційної системи. До оцінки ризиків слід залучати зовнішні до IT-служби відділи підприємства, а також сторонніх експертів.

У практиці розроблення інформаційних систем застосовуються різні стратегії $[1 ; 2 ; 4]$ :

1. Підхід від організаційної структури найчастіше використовується в інформаційній системі, яка базується на наявній структурі підприємства. Даний підхід не $\epsilon$ радикально новим, і реалізація інформаційної системи підприємства при цьому не вимагає перебудови наявної системи управління. Основним недоліком цього підходу є те, що застарілі системи та методи, які втрачають свою життєздатність через певний проміжок часу, скоріше за все, будуть перенесені у новостворену систему. Підхід від організаційної структури не враховує сутності інтегрованої природи більшості підприємств та дає можливість отримати мало інформації, яка виходить за межі підсистем. Даний підхід $\epsilon$ найбільш прийнятним, коли сфера діяльності підприємства досить консервативна.

2. Підхід із відкладеною інтеграцією є, по суті, підходом типу «вільної конкуренції» відносно створення інформаційної системи підприємства. Підсистеми компанії у цьому разі розвиваються лише тоді, коли в них існує потреба та не робиться спроб пристосуватися до визначених думок про те, як розроблятиметься інформаційна система підприємства. Для деяких підприємств такий підхід є оптимальним. Наприклад, компанія, що має декілька віддалених виробничих підрозділів, які вироблять різну продукцію, може дозволити їм розробляти власні інформаційні системи та вирішувати основні проблеми, передбачаючи подальшу інтеграцію інформаційних систем підприємства.

Цей підхід доцільно використовувати, коли немає цілісного уявлення про те, як розвиватиметься інформаційна система підприємства. Труднощі використання цього підходу полягають у тому, що незалежні підсистеми можуть розвиватися у великі системи, тому наступна інтеграція, якщо вона буде можлива, може виявитися складною та занадто дорогою. Також завдання остаточного об'єднання інформаційної системи може зіштовхнутися з більш серйозними проблемами, ніж просто затримка процесу інтеграції.

3. У рамках підходу, що базується на зборі даних, на першому етапі проєктування інформаційних систем підприємства особливе значення надається збору всіх необхідних даних, що можуть бути використані в системі, та їх класифікації. Цей процес дуже важливий, оскільки детальна класифікація зібраних даних допомагає зрозуміти, як вони використовуватимуться. 
4. Підхід, заснований на використанні баз даних, передбачає здійснення збору, зберігання та підтримки значної кількості даних, які повинні бути деталізовані настільки, щоб містити все необхідне для операційного та адміністративного управління у діловій сфері. Ця база даних використовується усіма підсистемами та користувачами, які за необхідності здійснюють доступ до неї. Бази даних підтримуються спеціальним програмним забезпеченням - системами управління базами даних, які відповідно до специфікацій користувачів можуть забезпечити безпеку, конфіденційність та точність даних. Відповідне програмне забезпечення вимагає його обслуговування відповідними фахівцями. Даний підхід, заснований на сучасній технології ведення баз даних, є досить перспективним, оскільки за нього забезпечується можливість за допомогою запитів надати користувачам безпосередній доступ до інформації.

5. Підхід «зверху вниз» передбачає визначення інформаційних потреб для всієї послідовності рівнів управління - від оцінки потреб управління до спільних цілей усього бізнесу. Якщо інформація, необхідна на вищому рівні управління, залишається відносно стійкою за ступенем детальності, змістом та частотою використання, то інформаційні системи можуть задовольняти ці вимоги. Цей підхід може бути виправданим у тому разі, коли існує різниця у типі інформації, що використовується на різних рівнях. Проте при цьому втрачаються основні переваги баз даних, які випливають із того, що цінність інформації визначається операцією та що вірогідність даних може бути встановлена у контексті операції, яка їх створює.

6. Загальносистемний підхід грунтується на припущенні, що ще до реалізації інформаційної системи певним способом можна розпізнати взаємозв'язки між частинами їі базової інформації. Процеси збору, зберігання та обробки даних проєктуються та реалізуються у рамках усієї системи у цілому.

7. Згідно з підходом, керованим подіями, підприємство можна охарактеризувати через ресурси, якими воно управляє. Очевидні ресурси - гроші, люди, запаси та засоби виробництва - легко ідентифікувати. Менш очевидні ресурси характеризують специфіку конкретного підприємства. Інформаційні системи підприємства, засновані на характеристиках його ресурсів, дають переваги не тільки в обслуговуванні та відображенні основних функцій управління, а й у готовності конкретних елементів даних до використання. Використовуючи цей підхід, можна отримати всю необхідну інформацію з документів підприємства, які відображають події, що відбуваються.

Потрібно зауважити, що всі методи розроблення інформаційних систем підприємств можна розділити на структурні та об'єктно-орієнтовані. Кожна із цих груп методів містить у собі декілька варіантів конкретних методик.

Структурні методи розроблення інформаційної системи мають такі основні особливості: розчленовування складної інформаційної системи на частини, так звані «чорні ящики», кожен з яких реалізує певну функцію системи управління; ієрархічне впорядкування виділених елементів інформаційної системи з визначенням взаємозв'язків між ними; використання графічного подання взаємозв'язків елементів інформаційної системи [2, с. 36].

Інформаційна модель, побудована із застосуванням структурних методів, $\epsilon$, по суті, ієрархічним набором діаграм, які графічно зображують функції, що виконуються інформаційною системою, та взаємозв'язки між ними. У діаграми також включається текстова інформація для забезпечення точного визначення змісту функцій та взаємозв'язків. За допомогою використання графічного подання процесів суттєво підвищується наочність моделі та полегшується процес ii сприйняття. Від рисунків, за допомогою яких можна уявити процес управління, структурні діаграми відрізняються тим, що вони виконуються за певними правилами, а процес їх складання та аналізу підтримується відповідним програмним забезпеченням.

До найпоширеніших методологій структурного аналізу належать такі: SADT - технологія структурного аналізу та проєктування інформаційних систем; DFD - діаграми потоків даних; ERD - діаграми «сутність - зв'язок»; STD - діаграми переходів станів.

Так, зокрема, у методології SADT використовуються чотири основних поняття: функціональний блок, інтерфейсна дуга, декомпозиція та глосарій. Функціональний блок позначає певну функцію у рамках розглянутої інформаційної системи та у графічному вигляді позначається прямокутником. За допомогою інтерфейсної дуги позначають елемент інформаційної системи, який обробляється функціональним блоком чи здійснює певний вплив на виконання блоком своєї функції. Графічно інтерфейсна дуга зображується у вигляді направленої стрілки. Декомпозиція передбачає розбивку складного процесу на складові частини. Рівень деталізації процесу визначається безпосередньо розробниками інформаційної моделі. У результаті загальна інформаційна модель процесу представляється у вигляді ієрархічної структури окремих діаграм, що робить їі доступнішою для огляду.

Модель SADT починається 3 уявлення процесу як єдиного функціонального блоку 3 інтерфейсними дугами, які виходять за межі розглянутої сфери. Ця діаграма називається контекстною. У пояснювальному тексті до неї необхідно зазначити короткий опис мети побудови діаграми та визначити так звану точку зору. Ціль визначає ті сфери діяльності підприємства, на які необхідно звернути увагу в першу чергу. У процесі декомпозиції функціональні блоки діаграми верхнього рівня деталізуються на діаграмі наступного рівня. Глосарій - це набір ключових слів, визначень, оповідальних викладів, які характеризують об'єкти, відображені на діаграмі. Глосарій забезпечує включення в діаграми SADT необхідної додаткової інформації.

У методології DFD досліджуваний процес також розбивається на підпроцеси та представляється у вигляді мережі, пов'язаної потоками даних. Суто зовні DFD подібна SADT, проте відрізняється за набором елементів, які використовуються. До них входять процеси, потоки даних та сховища. Сховище дає змогу в окремих випадках визначити дані, що зберігатимуться у пам'яті між процесами. Такого елемента в методологіï SADT немає, тому вважається, що DFD краще пристосована для побудови моделей створюваних систем 
автоматизації управління, тоді як SADT орієнтована на загальні аспекти побудови моделі системи управління.

Методологія ERD призначена для побудови моделей даних та забезпечує стандартизований спосіб опису даних та визначення зв'язків між ними. Основними елементами методології ERD $є$ поняття «сутність», «відношення» та «зв'язок». Сутності задають базові типи інформації, а відносини вказують, як ці типи даних взаємодіють між собою. Зв'язки поєднують сутності та відносини. ERD використовується, зокрема, для побудови моделей даних у сховищах DFD.

Методологія STD призначена для моделювання аспектів функціонування інформаційної системи, які залежать від часу чи реакції на події (робота в реальному часі). Основними елементами STD $є$ поняття «початковий стан», «стан», «перехід», «умова» та «дія». За допомогою цих понять описується поведінка інформаційної системи у часі та залежно від подій, що настають. Модель STD є графічним зображенням діаграми переходів системи $з$ одного стану в інший. Стани системи на цій діаграмі відображаються прямокутниками, а умови та дії - стрілками, які об'єднують стани. Методологія STD використовується також для опису залежної від часу поведінки системи в моделях DFD [1, с. 52].

Об'єктно-орієнтований підхід до побудови інформаційних моделей системи управління відрізняється від структурного підходу більшим рівнем абстракції та базується на уявленні інформаційної системи у вигляді сукупності об'єктів, що взаємодіють між собою шляхом передачі певних повідомлень. Об'єктами предметної сфери можуть виступати конкретні предмети чи абстраговані сутності: замовлення, клієнт тощо. У результаті використання об'єктно-орієнтованого підходу модель інформаційної системи так само, як і під час використання структурних методів, представляється сукупністю діаграм, які будуються за визначеними правилами.

Головними поняттями об'єктно-орієнтованого підходу є «об'єкт» та «клас». Об'єкт - це визначена сутність, яка відповідає певному предмету чи явищу та характеризується класом, станом та поведінкою. Для цих об'єктів, які взаємодіють між собою, можна створити різні моделі, які характеризують їх статичну структуру чи динамічну поведінку та розгортання у реальній роботі. Клас - це множина об'єктів, які пов'язані спільною структурою і поведінкою. Наступну групу важливих понять об'єктного підходу становлять поліморфізм (здатність класу належати більше ніж одному типу) i успадкування (побудова нових класів на основі наявних із можливістю додавання чи коригування даних i методів).
Сьогодні використовують значну кількість об'єктно-орієнтованих методів проєктування інформаційних систем. Прикладом об'єктно-орієнтованих методологій є методологія UML, що використовує графічні позначення для створення абстрактної моделі інформаційної системи. Цей стандарт був створений для визначення, візуалізації, проєктування і документування переважно програмних додатків. Методи описання результатів аналізу і проєктування UML семантично близькі до методів програмування на сучасних об'єктно-орієнтованих мовах.

Нині є нагальною потреба у нових засобах, спрямованих на скорочення термінів розроблення та високий рівень автоматизації інформаційних систем. Ця обставина стала причиною створення інструментальних засобів для швидкого розроблення додатків та засобів автоматизації практично всіх етапів життєвого циклу інформаційних систем. Багато із цих інструментів засновані на так званій методології RAD, яка охоплює всі етапи життєвого циклу сучасних інформаційних систем. За своєю сутністю та змістом методологія RAD - це комплекс інструментальних засобів, що дають змогу оперувати певним набором графічних об'єктів, які функціонально відображають окремі інформаційні компоненти додатків. Методологія заснована на трьох головних елементах: невелика команда програмістів (від 2 до 10 осіб); короткий, але ретельно підготовлений виробничий графік (від 2 до 6 місяців); ітераційній моделі - коли розробники, працюючи над додатком, періодично уточнюють у замовника його вимоги та реалізують їх у конкретному продукті [2]. Засоби RAD дають змогу реалізувати технологію створення додатків, коли інформаційні об'єкти формуються як певні діючі моделі.

Висновки. Таким чином, сучасне програмне забезпечення надає широкі можливості щодо організації формування, збереження та обробки інформації, дає змогу розвивати інформаційні технології для потреб управлінського персоналу підприємств та оперативного вирішення функціональних завдань. У практиці розроблення інформаційних систем застосовуються такі види стратегій: підхід від організаційної структури; підхід із відкладеною інтеграцією; підхід, що базується на зборі даних; підхід, заснований на використанні баз даних; підхід «зверху вниз»; загальносистемний підхід та підхід, керований подіями. Усі методи розроблення інформаційних систем підприємств можна розділити на структурні та об'єктно-орієнтовані.

Подальші розвідки у цьому напрямі стосуватимуться розроблення рекомендацій щодо вдосконалення інформаційних систем управління підприємством.

\section{Список використаних джерел:} $185 \mathrm{c}$.

1. Інформаційні системи і технології на підприємствах / укл. В.М. Охріменко, Т.Б. Воронкова. Харків : ХНАМГ, 2006.

2. Карпенко М.Ю., Манакова Н.О., Гавриленко І.О. Технології створення програмних продуктів та інформаційних систем. Харків : ХНУМГ ім. О.М. Бекетова, 2017. 93 с.

3. Савченко Л.А., Якимів Р.Я. Інформаційні технології на підприємствах агропромислого комплексу. Вісник Харківського національного технічного університету сільського господарства імені Петра Василенка. 2014. Вип. 147. С. $173-180$.

4. Шипунова О.В., Сльнікова Ю.В. Автоматизація управління підприємством: основні принципи, функції та підходи. Проблеми і перспективи розвитку банківської системи України. 2011. Вип. 31. С. 303-316. 
References:

1. Informatsiyni systemy i tekhnolohiyi na pidpryyemstvakh [Information systems and technologies in enterprises] (2006) / ukl. V.M. Okhrimenko, T.B. Voronkova. Kharkiv: KHNAMH. (in Ukrainian)

2. Karpenko M.Yu., Manakova N.O., Havrylenko I.O. (2017) Tekhnolohiyi stvorennya prohramnykh produktiv ta informatsiynykh system [Technologies for creating software products and information systems]. Kharkiv: KHNUMH im. O.M. Beketova. (in Ukrainian)

3. Savchenko L.A., Yakymiv R. Ya. (2014) Informatsiyni tekhnolohiyi na pidpryyemstvakh ahropromysloho kompleksu [Information technologies at the enterprises of agro-industrial complex]. Visnyk Kharkivskoho natsionalnoho tekhnichnoho universytetu silskoho hospodarstva imeni Petra Vasylenka, vol. 147, pp. 173-180.

4. Shypunova O.V., Yelnikova Yu.V. (2011) Avtomatyzatsiya upravlinnya pidpryyemstvom: osnovni pryntsypy, funktsiyi ta pidkhody [Automation of enterprise management: basic principles, functions and approaches]. Problemy i perspektyvy rozvytku bankivskoyi systemy Ukrayiny, vol. 31, pp. 303-316.

Shulha Olha

State University of Intelligent Technologies and Telecommunications

\section{MODERN APPROACHES TO THE DEVELOPMENT AND IMPLEMENTATION OF ENTERPRISE MANAGEMENT INFORMATION SYSTEMS: THEORETICAL AND METHODOLOGICAL ASPECT}

The purpose of the study is to summarize the existing theoretical and methodological approaches to the development and implementation of enterprise management information systems. To solve the tasks, such methods were used as: analysis and synthesis, deduction, generalization, system approach, etc. One of the effective ways to improve enterprise management is the development and implementation of modern management information systems and technologies. World practice shows that information systems are a powerful tool to increase productivity and production efficiency. The use of modern software products has a positive effect on the efficiency of the enterprise and increase its competitiveness.

It is emphasized that the strategy (or system of views) on its organization has a significant impact on the development information system of the enterprise. The information strategy must fully meet the goals and objectives facing the company, especially in the field of core business, as well as to promote the competitive advantages of the company in the market. The strategy of development of information technologies of the enterprise should follow directly from strategy of the company. The article describes formal and informal computer information systems. It is noted that in the practice of information systems development the following types of strategies are used: the approach from the organizational structure; deferred integration approach; a data collection approach; approach based on the use of databases; top-down approach; system-wide and event-driven approach. The essence and content of approaches to the development and implementation of information management systems of the enterprise are revealed, their comparative characteristics are carried out. The characteristic of structural and object-oriented methods of development of information systems of the enterprise is given. Emphasis is placed on the fact that the main advantages of using information technology in enterprise management are: cost reduction; optimization of accounting and control; ensuring transparency of information for investors; the possibility of increasing market share, etc. The practical significance of the obtained results is that they can be used to develop proposals for improving enterprise management information systems.

Key words: approaches, methods, information systems, information technologies, strategies.

JEL classification: M11, M20, O33 